Dorn, T., Ceelen, M., Buster, M., Stirbu, I., Donker, G., Das, K. Mental health and health-care use of detainees in police custody. Journal of Forensic and Legal Medicine: 2014, 26(aug), 24-28

nivel

\begin{tabular}{|l|l|}
\hline Postprint Version & 1.0 \\
\hline Journal website & $\underline{\text { http://www.sciencedirect.com/science/article/pii/S1752928X14001188 }}$ \\
\hline Pubmed link & http://www.ncbi.nlm.nih.gov/pubmed/25066169 \\
\hline DOI & $10.1016 /$ j.jflm.2014.06.005
\end{tabular}

This is a NIVEL certified Post Print, more info at http://www.nivel.eu

\title{
Mental health and health-care use of detainees in police custody
}

\author{
Tina Dorn ${ }^{\mathrm{A}}$, MANON CEelen ${ }^{\mathrm{A}}$, MARCel Buster ${ }^{\mathrm{A}}$, IRINA STIRBU ${ }^{\mathrm{B}}$, GÉ DONKER ${ }^{\mathrm{B}}$, KeES \\ DAS $^{\mathrm{C}}$ \\ ${ }^{a}$ Public Health Service, Department of Epidemiology \& Health Promotion, P.O. Box 2200, \\ 1000 CE Amsterdam, The Netherlands \\ ${ }^{\mathrm{b}}$ NIVEL, Netherlands Institute for Health Services Research, The Netherlands \\ ${ }^{\mathrm{c}}$ Public Health Service, Department of Forensic Medicine, Amsterdam, The Netherlands
}

\begin{abstract}
Background: In many countries, forensic physicians function as primary care providers for detainees in police custody. Their task is comparable to the tasks of general practitioners. Nevertheless, problems presented by both patient populations may differ. We therefore aimed to systematically compare presented problems and medication use in a population of police detainees to those of regular patients in general practice.

Methods: Health problems and prescription medications of 3232 detainees seen by the Amsterdam Forensic Medical Service were compared to those of general practice patients $(n=78,975)$ adjusted for age and gender during a 12-month period.

Results: Among those obtaining medical attention (28\% of all detainees), almost $50 \%$ were diagnosed with mental health problems, with substance abuse as the leading reason for consultation. Forty-two percent received at least one prescription affecting the nervous system. In general practice, $17 \%(P<0.001)$ of patients consulting their GP were diagnosed with mental health problems and $22 \%(P<0.001)$ were prescribed medications affecting the nervous system.

Conclusion: The magnitude of mental health problems among police detainees has significant implications for the qualifications of police health staff and those who provide health care in the police setting especially concerning substance abuse.
\end{abstract}

\section{INTRODUCTION}

Forensic physicians function as primary care providers for detainees in police custody in several countries. ${ }^{1}$ Health personnel in this setting are expected to treat acute health problems and to assess whether a stay in the police cell is safe, from a 
Dorn, T., Ceelen, M., Buster, M., Stirbu, I., Donker, G., Das, K. Mental health and health-care use of detainees in police custody. Journal of Forensic and Legal Medicine: 2014, 26(aug), 24-28

medical point of view. The health care issues of those detained by the police may differ from those seen in regular general practice for a variety of reasons. First of all, sociodemographic differences between the patient populations may exist, concerning age, level of education, socioeconomic status, access to health care prior to custody and ethnic background. ${ }^{2}$ Secondly, in police custody, acute health problems such as intoxication, withdrawal from illicit drugs and alcohol, psychiatric conditions and injury predominate the work of health staff., 4,5

From prison research, it is known that the prevalence of mental health problems and medical consumption among inmates is much higher than in the general population. ${ }^{6,7,8,9,10}$ Recent research performed among sentenced Dutch prisoners reports that $25 \%$ of all medical contact during custody included psychological aspects, while social problems and addiction were present in another $25 \%{ }^{11}$

Research performed among sentenced detainees is only partly informative for research on detainees held in police custody, however, as many of those arrested do not enter jail or prison because they are released at some stage following initial police contact. Moreover, lock-up only ranges from hours to a maximum of several days until the police investigations are finished. A look into the literature shows that, in contrast to prison populations, data concerning the mental health of police detainees are widely lacking. In police cells, only a few studies have been conducted so far. ${ }^{3,12,13,14,15,16,17,18,19,20}$ Information on the mental health of police detainees is necessary, however, with regard to patient safety in police custody.

Furthermore, knowledge on mental health issues of detainees helps inform those involved in the education of police health staff. A comparison of reasons for consultation in the police and general practice setting can provide valuable information concerning the different qualifications of health care providers needed. Last but not least, there is evidence for a positive relation between unresolved or untreated mental health problems in detainees and subsequent recidivism, underlining the importance of the topic to public health and society. ${ }^{21}$

Against this background, the aim of the current study is (1) to present a detailed description of the mental health problems for which primary care services were provided during police custody, (2) to shed light on differences in reasons for consultations of police detainees as compared to patients in general practice.

\section{METHODS}

The study is based on two sources of information:

(1) the electronic registration of the Forensic Medicine Department of the Amsterdam Public Health Service providing on-site health care to police detainees held in cell blocks of the Police Service Amsterdam-Amstelland during July 2008 to June 2009 ('detainee sample').

(2) data obtained from the Netherlands Information Network of General Practice

(LINH, 'general practice sample'), covering the year 2009.

\subsection{Detainee sample}

The primary care team of the Forensic Medical Service in Amsterdam delivers approximately 12,000 consultations to detainees annually. The team consists of forensic physicians and nurses employed by the Amsterdam Public Health Service. 
Dorn, T., Ceelen, M., Buster, M., Stirbu, I., Donker, G., Das, K. Mental health and health-care use of detainees in police custody. Journal of Forensic and Legal Medicine: 2014, 26(aug), 24-28

Care is provided at police stations and at cell blocks of the Police Service Amsterdam-Amstelland. In total, there are three cell blocks with a total capacity of 170 cells specially equipped for overnight stays (maximum stay: 6 days). In contrast to Dutch prisons, there is no standard medical intake of all incoming detainees. Instead, medical assessment may follow at the detainees' request or at the request of the police if health care issues (such as drug or medication use) are identified.

Health problems of detainees were coded electronically according to the International Classification for Primary Care (ICPC) by the care providers. ${ }^{22}$ Prescriptions were retrospectively coded for the purpose of this study using the Anatomical Therapeutic Chemical (ATC) classification. The ICPC is divided into 17 chapters based on the different body systems. The ATC classification categorises substances into fourteen main groups. Both classifications are considered important tools for presenting primary care and drug utilization statistics and are recommended for use in international comparisons. ${ }^{22,23}$ Between July 2008 and June 2009, 7888 consultations concerning 3232 patients took place in the three cell blocks in Amsterdam. Since the focus of this study is on mental health, we selected all consultations belonging to the ICPC-chapter 'Psychological' ( $n=4440$ out of 7888 consultations) and all prescriptions (4831 out of 9743 codes) belonging to the ATCcategory 'Nervous system'. An overview of somatic diagnoses and prescriptions is provided by Ceelen et al. ${ }^{2}$

\subsection{General practice sample}

In order to compare the mental health care provided to police detainees with the general practice setting, data from the Netherlands Information Network of General Practice (LINH) were obtained for the year 2009. The LINH database contains longitudinal data on morbidity, utilization of services, prescriptions and referrals of individuals subscribed to general practices in the Netherlands. For this study, we used information from 40 GP practices covering 91,215 persons aged 20-60 years subscribed to these GP practices. This age group was selected in order to achieve an age distribution comparable to that of the police detainee population. As a result, median age of the general practice population and detainee population visited by the forensic medical service was 41 years (25th-75th percentile 30-51) and 38 years (25th-75th percentile 28-47), respectively. As in the electronic registration of the Forensic Medical Service, diagnoses were coded using the ICPC (International Classification of Primary Care); prescriptions were coded according to the ATCclassification. Comparable to the detainee sample, we selected all consultations ( $n=$ 55,704 ) where at least one diagnosis belonging to the ICPC-chapter 'Psychological problems' was made and all prescriptions $(n=93,443)$ compromised by the ATCcategory 'Nervous system'.

\subsection{Analysis}

ICPC and ATC codes as registered by forensic doctors and nurses were summarized using descriptive statistics and compared to Dutch general practice data equivalent for age and gender. Differences between groups were analysed using chi-square test (categorical data) and $t$-tests (continuous data). Since one patient can present several problems during one consultation, and can receive more than one prescription following consultation, two levels of analysis are distinguished in Table 2 and Table 
Dorn, T., Ceelen, M., Buster, M., Stirbu, I., Donker, G., Das, K. Mental health and health-care use of detainees in police custody. Journal of Forensic and Legal Medicine: 2014, 26(aug), 24-28

3: (1) the patient level and (2) the consultation/prescription level. Significance testing in Table 2 and Table 3 refers to the consultation/prescription level (column 'diagnoses' in Table 2 and 'prescription' in Table 3), with the aim to describe differences between prescriptions issued and type of problems seen by general practitioners versus forensic physicians. All analyses were performed using SPSS 17.0 for Windows.

\section{RESULTS}

Between July 2008 and June 2009, 28\% of detainees were attended by a physician or nurse during custody ( $24 \%$ of all arrests in the police cell). During their stay at the police cell, 1609 patients were diagnosed at least once with an ICPC code from the chapter 'Psychological problems' (49.8\% of 3232 detainees with health care contacts during custody), whereas 1356 patients received at least one prescription belonging to the ATC-category 'Nervous system' (42.0\% of 3232 detainees with health care contacts during custody; Table 1). In general practice, in contrast, only $16.8 \%$ of patients consulting their GP were diagnosed with a mental problem. Nervous system medications were issued to $22.1 \%$ of GP patients.

\section{[TABLE 1]}

A comparison between the reasons for consultations observed in the detainee sample and the general practice sample shows numerous differences between the two settings of care (Table 2). Several problems are significantly more frequent in custody than in general practice. For example, the leading reason for consultation for male detainees in police custody is drug abuse (ICPC code P19; $54 \%$ of all consultations within chapter $\mathrm{P})$ compared to only $2 \%(p<0.001)$ of all consultations within chapter $\mathrm{P}$ in general practice. In female patients, this difference is even more pronounced: $60 \%$ among female detainees versus $0.4 \%(p<0.001)$ women in general practice. Among male detainees, chronic and acute alcohol abuse (ICPCcodes P15 + P16) together account for $19.6 \%$ of all consultations. In general practice, the corresponding percentage among male patients is $1.4 \%(P<0.001)$. In Table 3 , information on prescription medications was provided. Drugs used in addictive disorders account for $36.8 \%$ of all nervous system prescriptions to males in police custody, followed by anxiolytics (21.7\%) and antipsychotics (12.2\%). Also in female detainees, these three categories are leading.

\section{[TABLE 2]}

\section{[TABLE 3]}

\section{DISCUSSION}

This study investigated mental health problems among police detainees as compared to a reference population from regular general practice. Among those obtaining medical attention in the police cell (28\% of all detainees), almost $50 \%$ were seen due to mental health problems, with substance abuse as the leading reason for 
consultation. In addition, $42 \%$ of all detainees who obtained prescription medication during custody received at least one prescription affecting the nervous system. These figures are comparable to data provided in Dutch research reports dating back to the 1990s. ${ }^{24}$ Furthermore, they are in line with results from research performed in the same study population, which reported that nearly $40 \%$ of randomly selected police detainees were in need of further mental health assessment according to the Brief Jail Mental Health Screen. ${ }^{25}$

The comparison with GP data demonstrates that the percentage of patients with a mental diagnosis is three times the percentage observed in general practice. Regarding the percentage of patients with nervous system medication, twice as many patients from the detainee population when compared to the general practice population received this type of medication. Whereas drug abuse problems predominated the work of forensic physicians, these types of problems are relatively uncommon in general practice. On the other hand, some mental problems were significantly more often the reason for consultation in general practice when compared to the police setting, with depressive disorders as most prominent example. This can be explained by the circumstance that forensic physicians provide only short-term care, in contrast to general practitioners who are engaged in a long-term relationship with their patients. Mental health problems with an internalizing presentation such as depression therefore might not immediately come to the attention of the Forensic Medical Service. Moreover, the majority of GP patients will contact their doctor within a given period, whereas only $28 \%$ of police detainees were seen by the Forensic Medical Service. Given this, our findings should not be mistaken as prevalence estimates for mental health problems, but rather as a reflection of differences in reasons for consultations of police detainees as compared to patients in general practice. Possibly, pro-active screening for health problems could lead to the identification of more cases of depression among police detainees by the Forensic Medical Service. This could be valuable in particular with regard to suicide prevention. The value of systematic screening of police detainees has been emphasized in the past, as evaluations of current police screening procedures demonstrated that considerable proportions of physical and psychiatric morbidity are missed. ${ }^{12,20}$

Differences in problems presented by both patient populations also might be related to background characteristics of the groups studied. In our analyses, we adjusted for age and gender. Other factors such as marital and employment status, education, income and ethnic background were not registered by the forensic physicians, but very probably may explain part of the differences reported by our study. From surveys carried out among Amsterdam police detainees, it is known that those seen in police custody are more often low-educated, unemployed, single and belong to an ethnic minority group when compared to the general population. ${ }^{2}$ Moreover, they are more likely to suffer from chronic diseases than members from the general population. ${ }^{2}$ In addition to this, persons with substance abuse and/or externalizing psychiatric problems are more at risk of catching the attention of the police as they might cause nuisance in a public space and could endanger themselves or others by their behaviour. It therefore is not surprising that the difference between regular GP patients and detainees of the police is as large as described in our study. Finally, a few methodological limitations should be discussed. The current study was performed among an urban population. Results therefore are representative for police 
Dorn, T., Ceelen, M., Buster, M., Stirbu, I., Donker, G., Das, K. Mental health and health-care use of detainees in police custody. Journal of Forensic and Legal Medicine: 2014, 26(aug), 24-28

services in big cities. A potential limitation of the study is that we included police detainees held in cell blocks (which are especially equipped for overnight stays) and excluded those held in police stations throughout the city. From the literature, it is known that the percentage of detainees with mental health problems can strongly vary between sites. ${ }^{26}$ Overnight stays in cell blocks are more common among suspects of more serious offences as the police need more time for investigations. It is unclear how the type of offence of which a person is suspected relates to health outcomes. It is also possible that detainees in psychiatric crisis have already been diverted to health services in our study. Patients in acute psychiatric crisis therefore might have been underrepresented in our sample.

One of the strengths of the study is that reference data from GP practices has been provided. The provision of GP comparison data has the great advantage that differences in health care provision in both settings can be quantified. As we already stated above, prevalence claims should be avoided as this publication is based on the data of detainees seen by the Forensic Medical Service, and not the detainee population as a whole. Nevertheless, our description of the health problems for which primary care services were provided during police custody highlights the large difference between health problems seen in regular primary care and the police setting. It is evident that diagnosing and handling psychiatric patients and patients with problems of addiction and acute intoxication asks for appropriate clinical experience and specific competences. Our findings thus have significant clinical implications for those responsible for providing health services to the police cell population.

\section{Ethical approval}

None.

\section{Funding}

None.

\section{Conflict of interest}

We wish to confirm that there are no known conflicts of interest associated with this publication and there has been no significant financial support for this work that could have influenced its outcome.

We confirm that the manuscript has been read and approved by all named authors and that there are no other persons who satisfied the criteria for authorship but are not listed. We further confirm that the order of authors listed in the manuscript has been approved by all of us.

We confirm that we have given due consideration to the protection of intellectual property associated with this work and that there are no impediments to publication, including the timing of publication, with respect to intellectual property. In so doing we confirm that we have followed the regulations of our institutions concerning intellectual property.

Tina Dorn, on behalf of all co-authors. 
Dorn, T., Ceelen, M., Buster, M., Stirbu, I., Donker, G., Das, K. Mental health and health-care use of detainees in police custody. Journal of Forensic and Legal Medicine: 2014, 26(aug), 24-28

\section{ACKNOWLEDGEMENTS}

This study was supported by institutional funds provided by the Amsterdam Public Health Service. We also would like to express our gratitude to the AmsterdamAmstelland police force for enabling this research.

\section{REFERENCES}

1. Payne-James, JJ. History and development of clinical forensic medicine. In: M.M. Stark (Ed.), Clinical forensic medicine, Humana Press, Totowa, New Jersey (2005), pp. 1-36

2. Ceelen M, Dorn T, Buster M.C.A., Stirbu-Wagner I., Donker G., Das C. Health care issues and health care use among detainees in police custody. J Forensic Leg Med (2012) http://dx.doi.org/10.1016/j.jflm.2012.02.012

3. Payne-James J.J., Green P.G., Green N., McLachlan G.M., Munro M.H., Moore T.C. Healthcare issues of detainees in police custody in London, UK. J Forensic Leg Med, 17 (1) (2010), pp. 11-17

4. Payne-James J.J., Anderson W.R., Green P.G., Johnston A. Provision of forensic medical services to police custody suites in England and Wales: current practice. J Forensic Leg Med, 16 (4) (2009), pp. 189-195

5. Heide S., Stiller D., Lessig R., Lautenschlager C., Birkholz M., Fruchtnicht, W. Medical examination of fitness for police custody in two large German towns. Int J Legal Med, 126 (1) (2012), pp. 27-35

6. Fazel S., Danesh, J. Serious mental disorder in 23000 prisoners: a systematic review of 62 surveys. Lancet, 359 (9306) (2002), pp. 545-550

7. Fazel S., Bains P., Doll, H. Substance abuse and dependence in prisoners: a systematic review. Addiction, 101 (2) (2006), pp. 181-191

8. Fazel S., Baillargeon, J. The health of prisoners. Lancet, 377 (9769) (2011), pp. 956-965

9. Steadman H.J., Osher F.C., Robbins P.C., Case B., Samuels S.. Prevalence of serious mental illness among jail inmates. Psychiatr Serv, 60 (6) (2009), pp. 761-765

10. te Brake H., de Jong D., de Bakker D., Devillé, W. Health incarcerated: the use of medical services within correctional facilities. Eur J Public Health, 15 (Suppl. 1) (2005), p. 142

11. te Brake H., de Bakker D., Devillé W. Correctional health care for general practitioners: working circumstances, work satisfaction and burnout. 13th Wonca Europe conference, Paris, 17-20 october 2007 (2007) [Abstract on CD-rom

12. Baksheev G.N., Thomas S.D., Ogloff J.R. Psychiatric disorders and unmet needs in Australian police cells. Aust N Z J Psychiatry, 44 (11) (2010), pp. 1043-1051

13. Blaauw E., Kerkhof A., Vermunt R. Psychopathology in police custody. Int J Law Psychiatry, 21 (1) (1998), pp. 73-87

14. Blaauw E., Kerkhof A.D., Vermunt R. Suicides and other deaths in police custody. Suicide Life Threat Behav, 27 (2) (1997), pp. 153-163

15. Blaauw E., Vermunt R., Kerkhof A. Deaths and medical attention in police custody. Med Law, 16 (3) (1997), pp. 593-606

16. Stark M.M., Norfolk G., Rogers D.J., Payne-James J.J. The validity of self-reported substance misuse amongst detained persons in police custody. J Clin Forensic Med, 9 (1) (2002), pp. 25-26

17. Psychological distress among police arrestees. Med J Aust, 179 (8) (2003), pp. 408-411

18. McKinnon I., Grubin D. Health screening in police custody. J Forensic Leg Med, 17 (4) (2010), pp. 209-212

19. Lepresle A., Mahindhoratep T.S., Chiadmi F., Schlatter J., Boraud C., Chariot P. Police custody following drink-driving: a prospective study. Drug Alcohol Depend, 126 (1-2) (2012), pp. 51-54

20. McKinnon I.G., Grubin D. Health screening of people in police custody-evaluation of current police screening procedures in London, UK. Eur J Public Health, 23 (3) (2013), pp. 399-405

21. Sweeney J. Payne-James J.J. Poly drug use among police detainees. Trends \& Issues Crime Crim Justice, 425 (2011), pp. 1-8 
Dorn, T., Ceelen, M., Buster, M., Stirbu, I., Donker, G., Das, K. Mental health and health-care use of detainees in police custody. Journal of Forensic and Legal Medicine: 2014, 26(aug), 24-28

22. Lamberts H., Woods M. International classification of primary care. Oxford University Press, Oxford (1987)

23. World Health Organization. Introduction to drug utilization research. World Health Organization, Geneva (2003)

24. Blaauw E., Lulf R.E. Police custody detainees and forensic medicine: use of medical resources in the cell block. Med Law, 18 (1999), pp. 645-651

25. Dorn T., Ceelen M., Buster M.C.A., Das C. Screening for mental illness in Amsterdam police custody. Psychiatr Serv, 64 (10) (2013), pp. 1047-1050

26. Steadman H.J., Scott J.E., Osher F., Agnese T.K., Robbins P.C. Validation of the brief jail mental health screen. Psychiatr Serv, 56 (7) (2005), pp. 816-822

\section{TABLE 1}

\section{Characteristics of the detainee and the general practice (GP) sample ${ }^{\mathrm{a}}$}

\begin{tabular}{lcr}
\hline & $\begin{array}{l}\text { Detainee sample } \\
(n=3232)\end{array}$ & \multicolumn{1}{l}{$\begin{array}{l}\text { GP sample } \\
(n=78,975)\end{array}$} \\
\hline Men (\%) & $2762(86.3)$ & $35,597(45.1)^{* * *}$ \\
Age in years (SD) & $37.2(12.1)$ & $40.6(11.8)^{* * *}$ \\
Patients (\%) diagnosed with & $1609(49.8)$ & $13,279(16.8)^{* * *}$ \\
$\quad$ mental problem(s) & & $17,416(22.1)^{\mathrm{b}}$ \\
$\begin{array}{l}\text { Patients }(\%) \text { receiving nervous } \\
\quad \text { system medication }(\mathrm{s})^{\mathrm{c}}\end{array}$ & $1356(42.0)$ & \\
\hline
\end{tabular}

${ }^{*}: P<0.05,{ }^{* *}: P<0.01 ;{ }^{* *}: P<0.001$ (chi-square test for categorical data or $t$-test for continuous data).

a Both samples exclusively compromise persons with health care contacts.

b Defined as any problem belonging to the ICPC-chapter 'Psychological'.

c Defined as any prescription belonging to the ATC-category 'Nervous System'. 
Men

P19 Drug ajuse
P15 Chron. al cohol abuse
P01 Anxious/nervous
P99 Psych. dis. other
P16 Acute alcohol abuse
P72 Schizophrenia
P23 Adolesc. beh. sympt.
P76 Depressive disorder
P98 Psychosis NOS
P06 Sleep disturbance
P29 Psycholsympt. other
P03 Feeling depressed
P21 Hyperkinetic disorder
P71 Organic psychosis
(continued)P80 Personality disorder
P73 Affective psychosis
P04 Irritable/angry
P02 Acute stress reaction
P18 Medication abuse
P00 Family anamnesis
P77 Suicide attempt
P20 Memory disturbance
P28 Limited function
P70 Dementia

Other codes chapter $P$
Women

\begin{tabular}{|c|c|c|}
\hline \multicolumn{2}{|c|}{ Detainee sample } & \multirow{2}{*}{$\begin{array}{l}\frac{\text { GP sample }}{\text { Diagnoses }^{b}} \\
(n=20,721)\end{array}$} \\
\hline $\begin{array}{l}\text { Patients }{ }^{b} \\
(n=1357)\end{array}$ & $\begin{array}{l}\text { Diagnoses }^{b} \\
(n=39,46)\end{array}$ & \\
\hline 50.9 & 54.0 & $2.0^{\circ} \cdots$ \\
\hline 16.4 & 16.3 & $3.7 * \cdots$ \\
\hline 9.0 & 9.7 & 9.1 \\
\hline 8.6 & 5.0 & $3.5^{* * *}$ \\
\hline 5.3 & 3.3 & $0.4^{* *}$ \\
\hline 4.6 & 2.9 & $2.3^{*}$ \\
\hline 3.5 & 2.0 & $0.3^{* * *}$ \\
\hline 3.5 & 1.8 & $21.4^{* *}$ \\
\hline 1.8 & 1.1 & $1.5^{*}$ \\
\hline 2.1 & 0.9 & $11.7^{* * *}$ \\
\hline 2.1 & 0.9 & $3.2^{* * *}$ \\
\hline 1.1 & 0.5 & $5.6^{* * *}$ \\
\hline 0.9 & 0.4 & $2.5^{* * *}$ \\
\hline 0.7 & 0.3 & $0.5^{*}$ \\
\hline 0.5 & 0.3 & $2.0^{* * *}$ \\
\hline 0.4 & 0.2 & $1.6^{* * *}$ \\
\hline 0.4 & 0.2 & $1.3^{* * *}$ \\
\hline 0.2 & 0.1 & $3.6^{* * *}$ \\
\hline 0.2 & 0.1 & $1.7^{* *}$ \\
\hline 0.2 & 0.1 & 0.1 \\
\hline 0.2 & 0.1 & 0.2 \\
\hline 0.2 & 0.0 & 0.9 \\
\hline 0.2 & 0.0 & 0.2 \\
\hline 0.0 & 0.0 & 0.1 \\
\hline
\end{tabular}

Women

$\frac{\text { Patients }}{\mathrm{b}} \quad$ Diagnoses $^{\mathrm{b}} \quad \quad \frac{\text { GP sample }}{\text { Diagnoses }^{\mathrm{b}}}$

P19 Drug abuse

P01 Anxious/nervous

P99 Psych. disorders other

P15 Chron. alcohol abuse

P76 Depressive disorder

P23 Adolesc. beh. sympt.

P72 Schizophrenia

P98 Psychosis NOS

P16 Acute alcohol abuse

P29 Psychol.sympt. other

P06 Sleep disturbance

P09 Sex. pref. concern

P80 Personality disorder

P02 Acute stress reaction

P73 Affective psychosis

P03 Feeling depressed

P22 Child behav, sympt.

20.6

$53.260 .0 \quad 0.4 * *$

26.2

$11.0^{* *}$

$2.3^{* * *}$

$1.4^{* *}$

$29.0^{* * *}$

$0.2^{* *}$

1.2

1.0

$0.0^{*}$

$2.9^{* *}$

$13.2^{* *}$

$0.1^{*}$

$2.2^{* *}$

$3.7^{* * *}$

$2.1^{* *}$

0.7

$-$

$-$

Other codes chapter $\mathrm{P}$

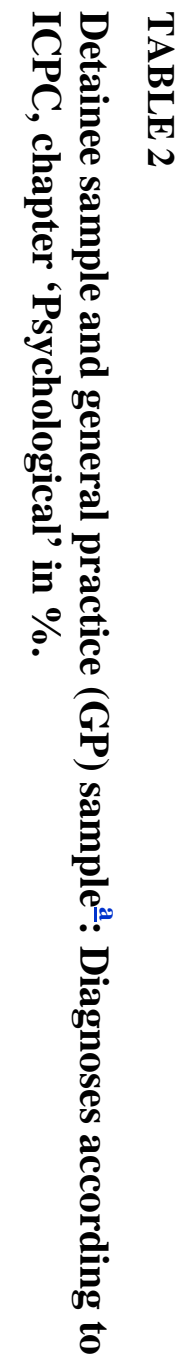

우 응

: $P<0.05,{ }^{*}: P<0.01:{ }^{* *}: P<0.001$ (chi-square test comparing $\%$ of ICPC-diagnoses in the detainee and GP samples).

a Both samples exclusively compromise persons with health care contacts.

b \% of ICPC-codes/patients within ICPC-chapter 'Psychological'. 


\begin{tabular}{|c|c|c|c|c|c|c|c|}
\hline \multicolumn{4}{|l|}{ Men } & \multicolumn{4}{|l|}{ Women } \\
\hline & \multicolumn{2}{|c|}{ Detaines sample } & \multirow{2}{*}{$\begin{array}{l}\frac{\text { GP sample }}{\text { Prescript-ions }} \\
(n=34,234)\end{array}$} & & \multicolumn{2}{|c|}{ Detainee sample } & \multirow{2}{*}{$\begin{array}{l}\text { GP sample } \\
\text { Prescript-ions }^{b} \\
(n=59,209)\end{array}$} \\
\hline & $\begin{array}{l}\text { Patients }{ }^{b} \\
(n=1146)\end{array}$ & $\begin{array}{l}\text { Prescript-ions }{ }^{b} \\
(n=4016)\end{array}$ & & & $\begin{array}{l}\text { Patients }{ }^{b} \\
(n=197)\end{array}$ & $\begin{array}{l}\text { Prescript-ions }{ }^{b} \\
(n=792)\end{array}$ & \\
\hline N07B Drugs addictive dis. & 45.5 & 36.8 & $18 \cdots$ & N07B Drugs addictive dis. & 51.3 & 35.1 & $1.1^{\cdots}$ \\
\hline N05B Anxiolytics & 31.0 & 21.7 & $195^{* *}$ & N05B Anxiolytics & 32.5 & 19.4 & $18.8^{* *}$ \\
\hline N05A Antipsychotics & 16.8 & 12.2 & $10.7^{* *}$ & N05A Antipsychotics & 19.8 & 13.3 & $6.4^{* *}$ \\
\hline N06A Antidepressants & 12.6 & 8.4 & $26.4^{\cdots}$ & N06A Antidepressants & 20.3 & 12.5 & $30.6^{* *}$ \\
\hline N03A Antiepileptics & 8.7 & 7.2 & 7.6 & N03A Antiepileptics & 10.7 & 5.3 & $5.5^{* \cdots}$ \\
\hline N02B Other analgesics & 12.7 & 4.9 & 4.6 & N05C Hypnotics/sed atives & 11.7 & 4.9 & $12.4^{* *}$ \\
\hline N05C Hypnotics/sedatives & 7.9 & 4.1 & $11.2 \cdots$ & N02B Other analgesics & 11.7 & 3.4 & $4.5^{\cdots *}$ \\
\hline N06B Psychostimulants & 2.8 & 1.8 & $2.8 \cdots$ & N04A Anticholinergica & 4.1 & 2.1 & $0.5 *$ \\
\hline N02A Opioids & 2.2 & 1.4 & $9.4 * *$ & N02A Opioids & 3.0 & 2.0 & $8.3^{* *}$ \\
\hline N04A Anticholinergica & 2.0 & 1.0 & 0.8 & N06B Psychostimulants & 2.0 & 1.5 & $0.8^{* * *}$ \\
\hline N02C Antimigraine prep. & 0.5 & 0.3 & $2.6 * *$ & N02C Antimigraine prep. & 1.0 & 0.3 & $8.2^{* *}$ \\
\hline N07C Antivertigo prep. & 0.2 & 0.0 & $0.8 \cdots$ & N07C Antivertigo prep. & 0.5 & 0.1 & $1.1^{\cdots *}$ \\
\hline N07A Parasympathomim. & 0.1 & 0.0 & 0.1 & & & & \\
\hline 'Nervous system', other & - & - & 18 & & - & - & 1.6 \\
\hline
\end{tabular}

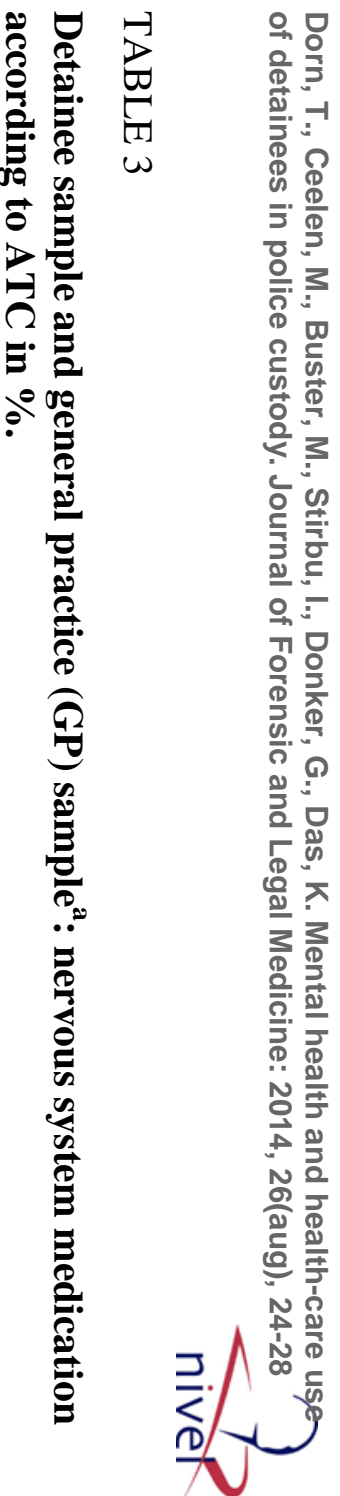

$\because P<0.05, \cdots: P<0.01 ; \cdots: P<0.001$ (chi-square test comparing $\%$ of prescription in the detainee and GP samples).

a Both samples exclusively compromise persons with health care contacts.

๖ $\%$ of prescriptions/patients within ATC-category "Nervous system". 